\title{
Costume and weapon simulator in the reconstruction of ancient martial arts practices
}

\section{An introduction}

\author{
Daniel Jaquet, \\ Castle of Morges, \\ daniel.jaquet@vd.ch
}

This international conference ${ }^{1}$ marked the end of an exhibition at the Castle of Morges entitled "Armatus Corpus: princes et chevaliers (1330-1530)". Intended as a broadening of some of the issues addressed in the exhibition through displays of objects and descriptions in the catalogue ${ }^{2}$, it questioned the role of weapons and clothing in martial practices, both in the late medieval period and in modern-day reconstructive practices.

Tobias Capwell opened the conference with a keynote "Arming the body for the joust, a modern issue for a new approach to a medieval sport", which considered the development of modern jousting practices from the early 1970s until today. This keynote was also given at the Wallace Collection ${ }^{3}$, and not included in these proceedings, since it was published in the collective book Turnier: 1000 Jabre Ritterspiele (Tournament: 1000 years of knightly games) ${ }^{4}$. The conference gathered scholars (historians, archaeologists, and museum curators), craftsmen, martial artists, and reenactors, who came together to exchange ideas from the perspectives of their own fields of expertise.

The conference included displays of objects, hands on sessions, demonstrations of martial arts, and a poster session. It echoed similar conferences ${ }^{5}$ with the same intent of

1 Workshop on costume and weapon simulators in the reconstruction of ancient martial arts practices, held in the Castle of Morges, 26-7th November, 2016. Organisation: Daniel Jaquet and Nicolas Baptiste. Supported by the International Federation of Historical European Martial Arts.

2 Baptiste, Nicolas (ed.), Armatus corpus: princes \& chevaliers, 1330-1530: 600 ans du duché de Savoie (Gollion: Infolio, 2016).

3 Capwell, Tobias, 'Deeds not words. A discussion of the History of Modern Jousting and some Thoughts on its Historical Importance', lecture of May 2017 given at the Wallace Collection, online: $\quad<$ http://www.wallacecollection.org/blog/2017/05/deeds-not-words-the-history-ofmodern-jousting/> [accessed 01.09.2017].

4 Capwell, Tobias, 'Ein Ritter des 21. Jahrhunderts.Praktische Erfahrungen bei historischen Turnierkämpfen um 1996-2014', in Turnier: 1000 Jahre Ritterspiele, ed. by Stefan Krause and Matthias Pfaffenbichler (München: Hirmer, 2017), pp. 355-80.

5 See the short reviews of Jaquet, Daniel, 'Conference Report - Mixing Fencing Ground and Academic Floor: A Review of Three Recent Conferences with a Focus on Historical European Martial Arts Studies', Martial Arts Studies 2, 2016, 118-21; and Jaquet, Daniel, 'Les Savoirs 
returning material culture to the centre of scholarly debate concerning embodied knowledge. It is quite difficult to report about such exchanges in writing. This volume gathers the scholarly contributions in a classical format, although most of the interesting exchanges and enhancement of knowledge building about material culture remains shared by the participants during the conference.

I will not introduce the different articles which are included as standalone written versions of the contributions in the present volume, but I will briefly outline some element of the contributions given by craftsmen and martial artists ${ }^{6}$.

\section{FORGOTTEN CRAFTS}

Gaël Fabre and Georges Jolliot are respectively a blacksmith and armourer renowned in the re-enactment and martial artists milieu in France and Switzerland. Both are expert craftsmen, knowledgeable in ancient objects and historical documents as part of their daily business, and both also contributed to the exhibition by crafting and loaning objects. Gaël Fabre explained his approach to blacksmithing in the company of Dominique Humbert, a scabbard maker. Georges Jolliot gave insights in to his craftsmanship in the company of Marcos Vinuesa, who specialises in armour decoration. Both were asked to highlight their relationship to historical objects and scientific research on material culture. They discussed several of the issues which face them regarding access to resources from academic or patrimonial institutions due to their professional activities, as they are both eager to contribute to knowledge building. Sharing experience is, however, difficult when one lacks the training or resources to actually write scientific articles. Moreover, written contributions are not the ideal medium to communicate skills and embodied knowledge.

Etienne von Gunten presented the work of Yann Charrière, a semi-professional dressmaker who specialises in medieval garments. This talk dealt with a case study regarding chausses, which considered issues noticed by martial arts practitioners when fighting in costume from the late medieval period. Chausses need to allow a full range of motion of the lower limbs and lower parts of the torso while "staying in place". He reviewed prototypes using different patterns and raw materials which are in use by martial artists and proposed a working solution. However, this is still under review in the cycles of ongoing experimentation.

Gestuels Investigués: L'expérimentation des Arts entre histoire des techniques, archéologie et histoire culturelle', E-Phaïstos : Revue d'histoire des techniques, 2 (2013), 119-22.

6 With the exception of the last article by Gassmann, Gassmann and Le Coultre, included in this volume (pp. 115-133), given alongside a demonstration of Historical European Martial Arts during the conference. 
The session led to interesting exchanges among specialists from the audience and from the contributors, including Marquita Volken and Julia Gräf, respectively a calceologist and an archaeologist, who both included object display in their presentations ${ }^{7}$.

\section{FORGOTTEN ARTS}

Olivier Gourdon and Rémi Poncelet presented their own approaches to Historical European Martial Arts. Both are trained martial artists with backgrounds in different martial practices, including MMA (Mixed Martial Arts) competitions. They outlined the need for a large variety of martial experiences for the study of HEMA and they illustrated their point with a demonstration of their interpretation of several fight books $^{8}$. They opposed two contexts of practices: serious situations and more playful context, while outlining where the inputs from their martial background actually helped in formulating interpretative hypotheses.

Piet Pollet and his comrades from The Hallebardiers (BE) offered their point of view of the practice of Historical European Martial Arts with little protective equipment whilst using steel simulators. The study of competitive and friendly training in the context of a guild suggests that daily or extraordinary practice was done in civil clothing with very little or no protection. Relying on such a little amount of protective gear actually tends to enhance one's ability to protect oneself. This kind of practice in the context of their own guild has proven itself by reducing double hits or "bad" fencing. They demonstrated their argument with fencing bouts.

The last demonstration was held by Swiss HEMA groups (Artes Certaminis, Gagschola, AMR, and Unil'AMHE) ${ }^{9}$ who offered some reflections on modern Historical European Martial Arts. A video presentation by the association Famaleonis ${ }^{10}$ of an annual reenactment armoured tournament, the Torneo in Armatura, also introduced questions surrounding armoured fighting into the debates.

\footnotetext{
7 Volken, pp. 25-45 and Gräf, pp. 47-71.

8 Their talk, entitled Lutte médiévale - une approche croisée d'arts martiaux anciens et modernes (Medieval Wrestling - an crossroad between ancient and modern martial arts), presented as interpretation of Fiore dei Liberi's Flos Duellatorum (1409) and Fabian Auerswald's Ringerkunst (1539).

9 Gassmann, Gassmann and Le Coultre, pp. 115-133.

10 Online: < http://www.torneoinarmatura.com/> [accessed 01.09.2017].
} 